\title{
CLINCHING JOINT FORMING SPEED IMPACT ON THE JOINTS STRENGTH
}

\begin{abstract}
This publication presents the impact of the forming speed of clinching joints on the static strength of a joint for DX51D + Z275 sheet material. For the chosen parameters of joined sheet materials (total sheet thickness $2 \mathrm{~mm}$ ) the geometry of forming tools, such as punch and die diameters (and radial clearance between the tools), the die depth and the parameter $\mathrm{X}$ (the minimum thickness of the joint embossment) were selected. The speed of joint formation (punch movement) was 3, 50 and $100 \mathrm{~mm} \cdot \mathrm{s}^{-1}$. To reduce the samples deformation during the tensile test the special apparatus was used. The mean values of forming parameters e.g., standard deviation and coefficient of variance of both forming and tearing forces were calculated. According to the ISO 12996-2013 standard the main strength structure parameters of clinching joints were determined.
\end{abstract}

Keywords: ISO 12996-2013, parameters of the joining technology, clinching

\section{Introduction}

The clinching joints, formed by using rigid tools with axisymmetric profile, are the group of connections most commonly used in the joining process of thinwalled structures. The main advantage of those tools is their simple geometry [1-3]. An example of clinching joint application in automotive industry was presented in fig. 1. The appropriate selection of tools parameters determines the size of interlock, which influences the strength of a joint. The change of the thickness of metal sheet and its arrangements creates the need to change the tool geometry (especially the punch and die diameter and the die depth) and the formation process parameter (the minimum dimension of the joint embossment parameter X). The change of these parameters influences not only the strength of a joint but also the process of energy consumption (especially the value of forming force) [4-9]. Other parameters of forming process, such as forming speed, stop time of a punch inside the material after the interlock formation, are chosen according to the directives of device manufacturers.

\footnotetext{
${ }^{1}$ Autor do korespondencji/corresponding author: Waldemar Witkowski, Rzeszow University of Technology, 8 Powstańców Warszawy Avenue, 35-959 Rzeszow, Poland, tel.: (17) 8651643, email: wwitkowski@prz.edu.pl
} 
There are no experimental studies on the impact of the formation speed of sheet metal joint on the connection strength. Hence, for the DX51D sheet material, an analysis of the impact of punch speed movements, during the interlock formation, on the strength of joints in the tearing test was presented.
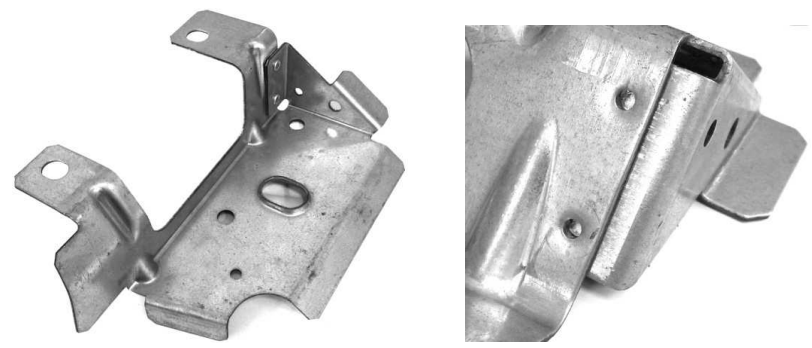

Fig. 1. Clinching joint in car bracket

\section{Experimental studies}

In the experimental studies the DX51D + Z275 sheets (material no. 1.0226), coated with galvanized zinc $275 \mathrm{~g} \cdot \mathrm{m}^{-2}$ were used. The thickness of joined sheets was $1 \pm 0.05 \mathrm{~mm}$. The samples with shape and dimensions presented in fig. $2 \mathrm{a}$ were joined by redrawing upper sheet in the lower sheet (clinching). The tools geometry and dimensions and the technological joining parameters were chosen according to the recommendations of the press manufacturer [10]. The punch diameter was $5.6 \mathrm{~mm}$, the die diameter was $8 \mathrm{~mm}$ and its depth was $1.85 \mathrm{~mm}$. The parameter $X$ was $0.5 \mathrm{~mm}$ ( $25 \%$ of the total thickness of joined sheet), and the radial clearance between the punch and the die was $1.2 \mathrm{~mm}$. The dimensions of the round rigid forming tools were presented in fig. $2 \mathrm{~b}$. The punch speed was $3 \mathrm{~mm} \cdot \mathrm{s}^{-1}$ (recommended by the press manufacturer), $50 \mathrm{~mm} \cdot \mathrm{s}^{-1}$ and $100 \mathrm{~mm} \cdot \mathrm{s}^{-1}$. There were five samples prepared for each value of the speed of joint formation.

The clinching joints were formed by using the Tox Pressotechnik Ltd. press in the laboratory of joint formed by pressing in the Department of Mechanical Engineering at the Rzeszow University of Technology. The maximum forming force of the press device was $100 \mathrm{kN}$ and the tools positioning precision was $0.01 \mathrm{~mm}$. The maximum error of the measurement and recording of the forming force in the function of the punch movement during the interlock formation was $0.5 \%$ of the forming force. To measure the real value of the parameter $\mathrm{X}$ the Mitutoyo digital device, with a measuring range of $20 \mathrm{~mm}$ and with the measurement accuracy of $0.01 \mathrm{~mm}$, was used.

The tearing tests of the clinching joints were done on the UTS 100 testing machine in the Research and Development Laboratory for Aerospace Materials at the Rzeszow University of Technology. Due to the dimensions and shapes of the samples a special apparatus, which allows to change the angle of a load 
force, was used. The traverse speed of the testing machine during the tearing test was $V=10 \mathrm{~mm} / \mathrm{min}$.

a)

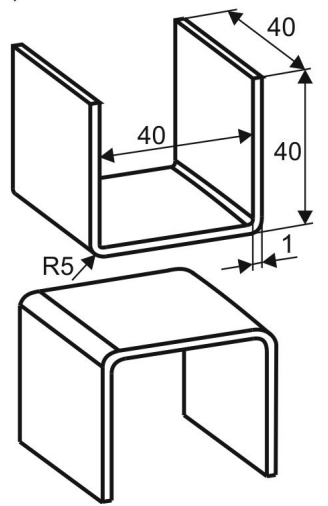

b)

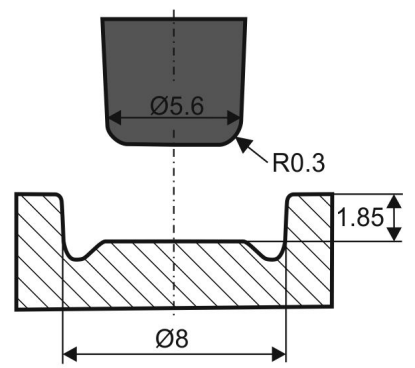

Fig. 2. Samples geometry: a) sheet material dimension, b) forming tools dimensions

\section{Results and analysis}

The possibility of making changes in technological process parameters in the press software significantly reduces the time of the process of formation. The parameters recommended by the press manufacturers refer to the total group of joined sheet materials. There is a need to select the appropriate geometry of forming tools for each joined sheet material, its thickness and arrangement $[6,10]$. Another important issue is the change of the parameters of forming process. The control unit of the press device was working according to the instructions of the process program. The next steps of the process program and the joining parameters are presented in tab. 1. and fig. 3. The forming speed of a joint was 3, 50 and $100 \mathrm{~mm} \cdot \mathrm{s}^{-1}$. The clinching joint samples and the tearing test were performed for the selected punch speed. The results of the tests and the calculation of the force mean values, standard deviations and coefficients of variance were presented in tab. 2 .

The use of the uniform rigid die in the clinching process ensures a relatively large repeatability of forming energy and maximum strength of joints (coefficient of variance $C_{v}<3 \%$ ). The increase of the speed of joint formation (from $3 \mathrm{~mm} \cdot \mathrm{s}^{-1}$ to $100 \mathrm{~mm} \cdot \mathrm{s}^{-1}$ ) results in the reduction of forming time and forming force $(7 \%)$. The force-displacement curves for different values of the speed of joint formation were presented in fig. 4. The use of H-shaped samples in the tearing test limits significantly the deformation of sheet metal. During the tearing test the embossments of the upper sheet were pulled out from the lower sheet without the loss of the material coherency. 
Table 1. Parameters of joining process

\begin{tabular}{|c|c|c|}
\hline \multirow{2}{*}{$\begin{array}{c}\text { Preparation } \\
\text { movements (1) }\end{array}$} & $\begin{array}{c}\text { The punch movement up to distance } \\
\text { of } 150 \mathrm{~mm} \text { from the die bottom }\end{array}$ & $V_{1}=50 \mathrm{~mm} \cdot \mathrm{s}^{-1}$ \\
\cline { 2 - 3 } & Stop of the forming tool & $t=0 \mathrm{~s}$ \\
\hline \multirow{2}{*}{$\begin{array}{c}\text { Forming } \\
\text { movements (2) }\end{array}$} & $\begin{array}{c}X=0.5 \mathrm{~mm} \\
V=3 \mathrm{~mm} \cdot \mathrm{s}^{-1} \\
V=50 \mathrm{~mm} \cdot \mathrm{s}^{-1} \\
V=100 \mathrm{~mm} \cdot \mathrm{s}^{-1}\end{array}$ \\
\cline { 2 - 3 } & $\begin{array}{c}\text { Forming movements with forming } \\
\text { force registration }\end{array}$ & $t=0 \mathrm{~s}$ \\
\hline $\begin{array}{c}\text { End process } \\
\text { movement (3) }\end{array}$ & Stop of the forming tool & $V_{2}=10 \mathrm{~mm} \cdot \mathrm{s}^{-1}$ \\
\hline
\end{tabular}

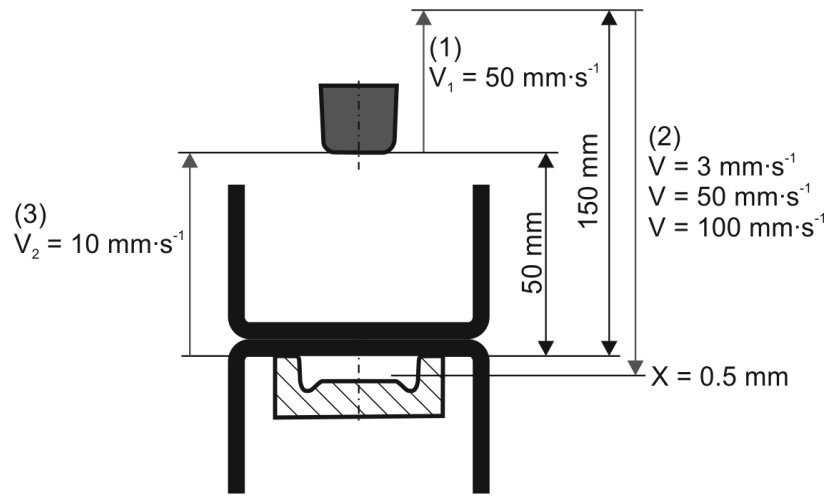

Fig. 3. Stages of joint forming process

Table 2. Joint cycle time, forming force (mean value, standard deviation and coefficient of variance), tearing force (mean value, standard deviation and coefficient of variance)

\begin{tabular}{|c|c|c|c|}
\hline Parameter, unit & $V=3 \mathrm{~mm} \cdot \mathrm{s}^{-1}$ & $V=50 \mathrm{~mm} \cdot \mathrm{s}^{-1}$ & $V=100 \mathrm{~mm} \cdot \mathrm{s}^{-1}$ \\
\hline Process time $t[\mathrm{~s}]$ & 58.090 & 10.920 & 9.580 \\
\hline Forming force $F_{f}[\mathrm{kN}]$ & 73.840 & 72.814 & 68.380 \\
\hline Standard deviation $s[\mathrm{kN}]$ & 0.885 & 0.529 & 0.558 \\
\hline Coefficient of variance $C_{v}[\%]$ & 1.270 & 0.770 & 0.870 \\
\hline Tearing force $F[\mathrm{kN}]$ & 2.066 & 2.034 & 2.024 \\
\hline Standard deviation $s[\mathrm{kN}]$ & 0.038 & 0.028 & 0.030 \\
\hline Coefficient of variance $C_{v}[\%]$ & 1.950 & 1.480 & 1.580 \\
\hline
\end{tabular}

The strength of clinching joints, for different values of the speed of joint formation, was presented in fig. 5. According to the ISO 12996 standard [11] the main joints strength parameters are:

- dissipated energy up to fracture (work or area under the load curve),

- dissipated energy up to maximum load force (area under the force curve up to the point of maximum tearing load), 
- total displacement (maximum increase of the specimen during tearing test),

- displacement at the maximum load force (amount of displacement measured at maximum load force),

- the maximum load force recorded in the test.

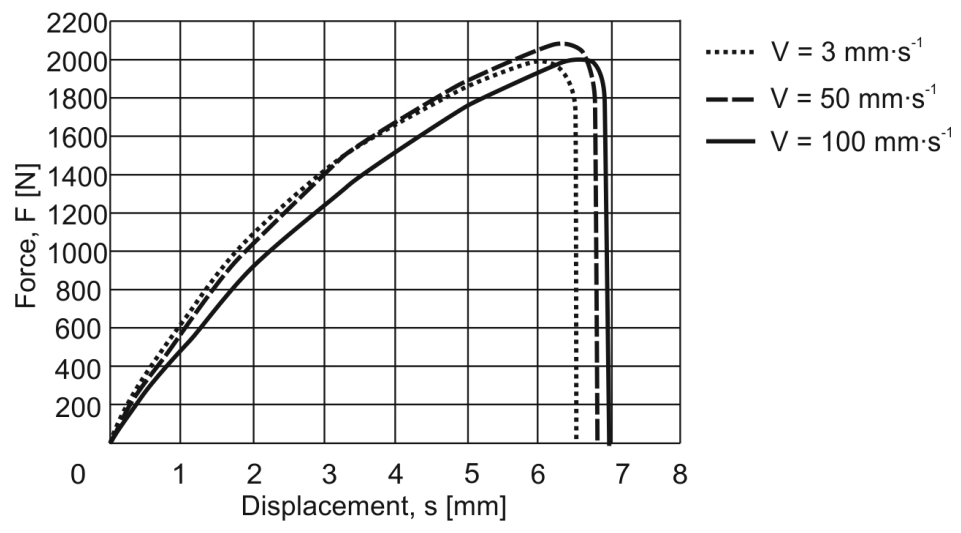

Fig. 4. Force-displacement curves during the tension test

The separation of the joined sheets was caused by exceeding the maximum load force, for which the upper sheet material is pulled out from the bottom sheet. The difference between the maximum displacement and the displacement for the maximum load force was about $8 \%$. The energy destruction for the maximum joint load force was over $90 \%$ of the total energy destruction. For the selected values of the speed of joint formation there were no significant changes in the strength of a joint during the tearing test. It may be caused by the proper choice of the tools geometry and the process parameters, where the material volume of the embossment ensures the proper size of the interlock and the strength of a joint.

\section{Conclusions}

- From the analysis of the results of the experiment it can be concluded that: coefficients of variance $\left(C_{v}<3 \%\right)$ of both forming and maximum loading forces correspond to the high repeatability of the strength of round clinching joints in the tearing test,

- the sheet metal separation during the tearing test occurs immediately after exceeding the maximum loading force,

- the change of the speed of joint formation, during the interlock formation with tool geometry chosen according to the directives of device manufactures, do not affect the strength of a joint in tearing tests, 
- the increase in speed of the joint formation reduces the value of forming force and the time of forming process.

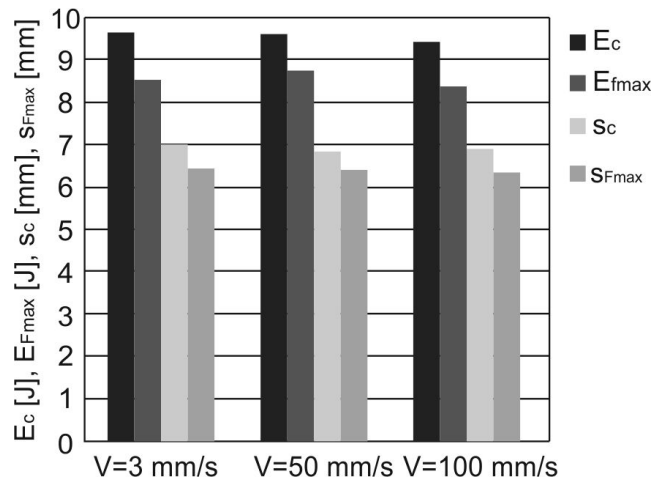

Fig. 5. Strength of clinching joint during the tearing test realized according to ISO 12996 standard

\section{References}

[1] Mucha J.: Współczesne techniki łączenia cienkich blach - zaciskanie przez wytłaczanie (Clinching). Mechanik, 80 (2007), 932-939.

[2] Mucha J., Kaščák L.: Some aspects of the forming of round clinching joints. Problemy Eksploatacji, 4 (2010), 29-38.

[3] Neugebauer R., Voelkner, W., Mauermann, R., Israel, M.: Clinching in steel and railway construction, shipbuilding and commercial vehicles. J. Prod. Eng., 16 (2013), 63-68.

[4] Coppieters S., Lava P., Baes S., Sol H., VanHoutte P., Debruyne D.: Analytical method to predict the pull-out strength of clinched connections. Thin-Walled Structures, 52 (2012), 42-52.

[5] Varis J.P.: Ensuring the integrity in clinching process. J. Mat. Proc. Technol., 174 (2006), 277-285.

[6] Mucha J., Kaščák L., Spišák E.: Joining the car-body sheets using clinching process with various thickness and mechanical property arrangements. Arch. Civil Mech. Eng., 11 (2011), 135-148.

[7] Mucha J., Witkowski W.: Eksperymentalna analiza efektywności rozwiązań wybranych systemów łączenia przez przetłaczanie blach. Technol. Automatyzacja Montażu, 23 (2013), 55-60.

[8] He X., Zhao L., Yang H., Xing B., Wang Y., Deng Ch., Gu F., Ball A.: Investigations of strength and energy absorption of clinched joints. Comput. Mat. Sci. 2014: dx.doi.org/10.1016/j.commatsci.2014.01.056.

[9] Mucha J., Witkowski W.: The clinching joints strength analysis in the aspects of changes in the forming technology and load conditions. Thin-Walled Structures, 82 (2014), 55-66, http://www.sciencedirect.com.

[10] http://www.tox-pl.com.

[11] ISO 12996-2013: Mechanical joining - Destructive testing of joints - Specimen dimensions and test procedure for tensile shear testing of single joints. 


\section{WPLYW PRĘDKOŚCI FORMOWANIA ZLĄCZA TYPU CLINCHING NA WYTRZYMAŁOŚĆ POŁĄCZEŃ}

\section{Streszczenie}

W publikacji przedstawiono wpływ prędkości formowania złączy przetłoczeniowych typu clinching na wytrzymałość statyczną dla materiału blach DX51D + Z275. Dla ustalonych parametrów łączonych blach (grubość całkowita $2 \mathrm{~mm}$ ) dobrano geometrię narzędzi formujących: średnice stempla i matrycy (luz promieniowy), głębokość dna w wykroju matrycy, parametr X (minimalna grubość przetłoczenia złącza). Prędkość formowania złącza (ruch roboczy stempla) wynosiła: 3, $50 \mathrm{i} 100 \mathrm{~mm} \cdot \mathrm{s}^{-1}$. W celu ograniczenia deformowania się pasm blach w testach wytrzymałościowych wykorzystano specjalnie zaprojektowany uchwyt. Wyznaczono wartości średnie sił formowania, sił rozrywających złącze, odchylenia standardowe oraz współczynniki zmienności. Zgodnie z normą ISO 12996-2013 określono główne parametry struktury wytrzymałościowej złączy przetłoczeniowych.

Słowa kluczowe: ISO 12996-2013, parametry technologiczne, clinching

DOI: $10.7862 / \mathrm{rm} .2014 .67$

Otrzymano/received: $24.06 .2014 r$.

Zaakceptowano/accepted: 22.10.2014 r. 
